\title{
Rorschach Comprehensive System Norms in Brazilian Children from Public and Private Schools
}

\author{
Normas do Rorschach Sistema Compreensivo para Crianças Brasileiras \\ de Escolas Públicas e Escolares Particulares
}

\author{
Rosangela Kátia Sanches Mazzorana Ribeiro ${ }^{*}, a$, Norma Lottenberg $\operatorname{Semer}^{b}$ \& Latife Yazigi ${ }^{b}$ \\ ${ }^{a}$ Universidade de Mato Grosso, Cuiabá, Brasil \& ${ }^{b}$ Universidade Federal de São Paulo, São Paulo, Brasil
}

\begin{abstract}
The objective of this study was to construct normative tables for the Rorschach Comprehensive System for Brazilian children from public and private schools. The sample was selected using the Child Behavior Checklist and the Raven Test. The Rorschach was administered to children from 7 to 10 years old, both genders, from public schools $(N=110)$ and private schools $(N=101)$ in the city of Cuiabá, Mato Grosso State. Normative tables were created from the 113 variables of the Rorschach Comprehensive System, taking into consideration school type and age group. A comparison of the results demonstrated higher results in the $R$, Sum $Y$ and Blend variables and in the Intellectualization Index among private school children, and higher Lambda scores among public school children.

Keywords: Rorschach Comprehensive System; Normative Tables; Children; Private Schools; Public Schools.

Resumo

O objetivo foi construir tabelas normativas do Rorschach Sistema Compreensivo para crianças brasileiras alunas de escolas particulares e públicas. A amostra foi selecionada por meio da Child Behavior Checklist e do teste de Raven. O Rorschach foi aplicado em crianças de 7 a 10 anos, de ambos os gêneros, de escolas públicas $(N=110)$ e particulares $(N=101)$, da cidade de Cuiabá, MT. Foram construídas tabelas normativas das 113 variáveis do Rorschach SC considerando origem escolar e faixa etária. A comparação dos resultados demonstrou resultados mais elevados nas variáveis $R$, Sum $Y$, Mistos e Índice de Intelectualização nas crianças de escola particulares e na variável Lambda nas crianças de escolas públicas.

Palavras-chave: Rorschach Sistema Compreensivo; Tabelas Normativas, Crianças; Escolas Particulares; Escolas Públicas.
\end{abstract}

Since the publication of Psychodiagnostics by Hermann Rorschach, many researchers from different countries have conducted studies using the test, with a view to broadening and systematizing the technique. As such, the differences between the lines pursued by these specialists resulting from their professional experiences have had repercussions on the application and codification procedures, giving rise to various systems with distinct approaches and interpretations.

In 1969, John Exner published a comparative analysis of the five most popular Rorschach systems in the United States. This comparison was motivated by Samuel Beck and Bruno Klopfer, who recommended a careful examination of the differences presented in the different systems and referenced in their articles (Beck, Beck, Levitt, \&

" Address: Rua Desembargador José de Mesquita, 255, Edifício Sunset Boulevard, apto. 1401, Bairro Araés, Cuiabá, MT, Brasil, CEP 78005-560. E-mail: rosangelaksm@uol.com.br

Agradecimentos: À Coordenação de Aperfeiçoamento de Pessoal de Nível Superior (CAPES), pelo auxílio bolsa de doutorado.
Molish, 1961; Klopfer \& Boyer, 1961). Specialists who used the systems developed by Hertz, Piotrowski and Rapapport/Shaffer called for a broader comparison including all five systems. This resulted in the project to write a book, which took seven years. The final result illustrated the magnitude of the differences between the systems, making the idea of creating "a single Rorschach" look more like a myth than a reality - there were five different systems, similar only in their use of the same cards. These difficulties led John Exner to establish the Rorschach Research Foundation in 1968 and to start investigations to integrate the various characteristics of the systems, seeking to codify, systematize, objectivize and standardize the Rorschach data and validate them in relation to the observable behavior, in accordance with Exner and Weiner (1995a).

This led to the creation of the Comprehensive System (Exner, 1974), whose approach to Rorschach interpretation was empirically grounded and rigorous from a psychometric standpoint. However, as the author points out, there is nothing to stop the data from being interpreted in accordance with a given theoretical basis (Exner, 1993). 
In the Comprehensive System, the Rorschach is a method that transcends theoretical bases. It is not linked to a specific theory of personality or a specific concept of mental functioning. Notions and concepts of different approaches help describe and explain the results of the Rorschach, and generate useful information independently of any theory, as stated by Weiner (2000).

The Rorschach responses have similar implications concerning the characteristics of personality, regardless of the age of the subject under evaluation. Nevertheless, these characteristics inferred from the Rorschach responses may differ depending on the adjustment of the subjects of different ages. Therefore, conclusions about the extent to which the responses are adapted or not derive from the existence of a standard reference in relation to age, gender and socioeconomic and cultural conditions, so an adequate interpretation can be made of the subject, whether a child or an adult, as pointed out by Exner and Weiner (1995b).

Evaluating the personality of a child is a complex and difficult task, given the changes resulting from growth. According to Exner and Weiner (1995b):

There exists in the subject in development a wide range of individual differences that are developed each year, from a cycle prior to the current time of each child that continues until adulthood. Another issue of concern is the extensive growth changes that can occur within a single chronological year. Many findings from developmental psychology suggest that it is unreasonable to judge all children within a single year by one standard. (p. xiii).

Shaffer, Erdberg and Meyer (2007) affirm that the norms of children in different countries are the result of characteristics related to the expression of the cultural, social and economic life of each country, and that this is also revealed in the Rorschach Method. Although the interpretive meanings involve descriptions of the universally applicable personality, the meaning of the results in adaptive terms depends on normative standards. Some Rorschach data show that the indices transcend cultural differences, while other data show that a variation of personality traits in a normal range reflects the description of the personality in terms of tailoring adjustment to real life, as emphasized by Meyer, Erdberg and Shaffer (2007).

Normative studies with children, both Brazilian and from other countries, have been concerned with defining some criteria for the selection of the sample, such as: size of the age group, number of subjects, criteria for inclusion/ exclusion in the sample and school origin, according to Shaffer et al. (2007). In relation to normative data, Pasquali (2003) mentions that the result of the subject makes sense in relation to the scores of all the subjects of the population for which the test was developed, but since the scores of all the population are not known, a representative sample is used to establish reference norms.

For this reason, a delineation was made that took into consideration the molds of other Brazilian studies (Jacquemin, 1975; Raspantini \& Pasian, 2008; Resende, Rezende, \& Martins, 2006) and studies from other countries, such as those cited in Meyer et al. (2007). This meant it could be considered, both in terms of methodological rigor and in the size of the sample, as having a certain equivalence with the other studies, allowing the normative tables to be used by professionals and academics elsewhere in Brazil. This does not, however, preclude the need for studies in other places so as to allow a comparison between groups, taking into account the cultural conditions of each region.

With a view to contributing to the study and use of the Rorschach Method in children and thereby making it more adapted and tailored to Brazilian children and, more specifically, to a particular region of Brazil, this research considered the concerns of academics such as Adrados (1985), Barreto (1950/1955), Jacquemin (1975), Viana (1958) and Windholz (1969), who contributed with nor-mative studies for Brazilian children. These studies date back to a time when the socio-economic and cultural reality was very different from the present reality, and these references illustrate that more than 20 years have passed without producing studies of this scale in Brazil. Research is currently being conducted by Raspantini and Pasian (2008), in the French School of Psychoanalysis, with a sample of children from Ribeirão Preto, in the state of São Paulo, and by Resende et al. (2006), in the Comprehensive System, with children in Goiânia, in the state of Goiás.

This research was conducted given the lack of normative studies with the Rorschach Method in Brazil, particularly with children.

\section{Selection and Instruments Used to Select the Participants}

Pupils were selected from two public schools $(N=110)$, one from the central region and one from the suburban region, and from three private schools $(N=101)$, one religious and two secular. The following criterion was used as representation of the social classes: public school caters to the lower and lower-middle classes (C2, D and E) and private school caters to the middle, upper-middle and upper classes (A1, A2, B1, B2 and C1), according to the Brazilian Association of Market Research Institutes (2008).

Two instruments were used to guarantee a sample of pupils without behavioral problems or intellectual difficulties that could undermine a normative study: (a) the Child and Adolescent Behavior Checklist - Brazilian Version of the "Child Behavior Checklist" (CBCL/6-18 of Achenbach) that assesses social competence and behavioral problems in children and adolescents aged 6 to 18 years, based on information supplied by the parents (Achenbach, 1991). The validation studies demonstrated the high sensitivity of the Brazilian version compared to the "gold standard" of psychiatric diagnosis based on the International Classification of Diseases and Related Health Problems - ICD-10, the Diagnostic and Statistical Manual of Mental Disorders - DSM-IV, according to Bordin et al. (2009), Bordin, Mari and Caieiro (1995), and the work of Brasil (2003). The instrument gives a score of "Social Competence", "Internalized Problems", 
"Externalized Problems" and "Total Behavioral Pro-blems" that classify the child as clinical, borderline or non-clinical. (b) The Raven Colored Progressive Matrices Test (Raven, Raven, \& Court, 1993), which is one of the most commonly used tests to assess intellectual develop-ment of children aged 5 to 11 years, in the version adapted to Brazil by Angelini, Alves, Custódio, Duarte and Duarte (1999) in its method of application and use of normative tables.

\section{Procedures}

The CBCL questionnaire was completed by the parents or guardians $(N=386)$ of each child, at the school where the children study. The results were classified in percentiles, in accordance with Achenbach (1991): percentiles $>91$ clinical cases, percentiles between $84-90$ borderline cases and percentiles $<84$ non-clinical cases. For this study, only the non-clinical cases were included in the final sample, or 224 children (59\% of 386), since 48 (11\%) were classified as borderline cases and $114(30 \%)$ as clinical cases.
The 224 children without behavioral problems were administered the Raven Colored Progressive Matrices Test, which was applied individually to the 7 year olds and collectively to the 8-10 year olds, in accordance with the standardization provided by the test manual (Angelini et al., 1999). The administrations were conducted at the schools, in exclusive rooms. Six children were excluded who presented percentiles below 25 , which indicates below average intellectual capacity, according to the normative tables of the Brazilian adaptation of Angelini et al. (1999). Seven children withdrew from the study after they were transferred from the participating schools during the data collection period.

After the selection, the Rorschach Method, Comprehensive System, was applied to 211 children of both genders, aged 7-10, subdivided into two groups according to school origin: public $(N=110)$ and private $(N=101)$; and age group: 7 year olds $(N=50), 8$ year olds $(N=53), 9$ year olds $(N=53)$ and 10 year olds $(N=55)$, in accordance with Table 1.

Table 1

Distribution of the Sample (N=211) by Age, Gender and School Origin

\begin{tabular}{lcccccccc}
\hline Age & 7 year olds $(N=50)$ & \multicolumn{2}{c}{8 year olds $(N=53)$} & 9 year olds $(N=53)$ & \multicolumn{2}{c}{ 10 year olds $(N=55)$} \\
\hline Gender & $\mathrm{F}$ & $\mathrm{M}$ & $\mathrm{F}$ & $\mathrm{M}$ & $\mathrm{F}$ & $\mathrm{M}$ & $\mathrm{F}$ & $\mathrm{M}$ \\
\hline Public School & 11 & 12 & 12 & 12 & 15 & 15 & 16 & 17 \\
Private School & 14 & 13 & 14 & 15 & 10 & 13 & 09 & 13 \\
Total & 25 & 25 & 26 & 27 & 25 & 28 & 25 & 30 \\
\hline
\end{tabular}

Note. $\mathrm{F}=$ Female; $\mathrm{M}=$ Male.

Economic and Educational Condition of the Parents of the Children Involved in the Study

The economic condition of the participants was not formally researched. However, there was some control in relation to the type of employment held by the parents.

The children participating in the study were enrolled in the $1^{\text {st }}$ to $4^{\text {th }}$ grade of primary education at the time of the assessment and the correspondence between the chronological age and the school grade was taken into consideration. Since it was a study with children, some relevant

Table 2

Schooling of the Parents of the Children from Private Schools

\begin{tabular}{lrrrr}
\hline & \multicolumn{2}{c}{ Mother $(N=101)$} & \multicolumn{2}{c}{ Father $(N=101)$} \\
\cline { 2 - 5 } Schooling & $N$ & $\%$ & $N$ & $\%$ \\
\hline Illiterate & 00 & 0.0 & 00 & 0.0 \\
Incomplete primary & 00 & 0.0 & 02 & 2.0 \\
Complete primary & 00 & 0.0 & 00 & 0.0 \\
Incomplete secondary & 01 & 1.0 & 02 & 2.0 \\
Complete secondary & 09 & 8.9 & 18 & 17.8 \\
Incomplete higher & 11 & 10.9 & 09 & 8.9 \\
Complete higher & 66 & 65.3 & 63 & 62.4 \\
Postgraduate & 14 & 13.9 & 04 & 4.0 \\
Deceased & 00 & 0.0 & 03 & 3.0
\end{tabular}

information about the parents was prioritized, such as schooling, employment and with whom the child was living at the time of the assessment. Tables 2 and 3 show the schooling of the parents, Table 2 for the parents of the children from private schools and Table 3 for the parents of the children from public schools.

Table 2 shows that the schooling of most of the parents of the children from private schools ranges from completed secondary education to a postgraduate degree, while the majority have some higher education degree.

Table 3

Schooling of the Parents of the Children from Public Schools

\begin{tabular}{lrrrr}
\hline & \multicolumn{3}{c}{ Mother $(N=110)$} & \multicolumn{2}{c}{ Father $(N=110)$} \\
\cline { 2 - 6 } Schooling & $N$ & $\%$ & $N$ & $\%$ \\
\hline Illiterate & 01 & 0.9 & 03 & 2.7 \\
Incomplete primary & 24 & 21.8 & 37 & 33.6 \\
Complete primary & 10 & 9.1 & 13 & 11.8 \\
Incomplete secondary & 18 & 16.4 & 10 & 9.2 \\
Complete secondary & 47 & 42.8 & 33 & 30.0 \\
Incomplete higher & 03 & 2.7 & 04 & 3.6 \\
Complete higher & 04 & 3.6 & 01 & 0.0 \\
Postgraduate & 00 & 0.0 & 00 & 0.0 \\
Don't know & 03 & 2.7 & 09 & 8.2 \\
\hline
\end{tabular}


Table 3 shows that the schooling of most of the parents of the children from public schools ranges from incompleted primary education to completed secondary education, although the majority have completed their secondary education.

The information on the occupation of the parents was obtained in the pre-selection stage of the sample, when the CBCL was administered. The occupations were grouped in accordance with economic sectors, subdivided into the primary sector - related to production through the exploration of natural resources, such as agriculture, mining, fishing, livestock farming, plant extractivism and hunting, a sector that supplies raw materials to manufacturers; the secondary sector, which transforms raw materials into manufactured products, such as clothing, machinery, automobiles, food, domestic appliances; and the tertiary sector, related to services such as commerce, education, health care, telecommunications, computing, insurance, transport, cleaning, tourism, banking and administration. Tables 4 and 5 show the relation between the economic sectors and the occupations of the parents, Table 4 for the parents of the children from private schools and Table 5 for the parents of the children from public schools.

Table 4

Relation of Economic Sectors with the Occupation of Private School Parents

\begin{tabular}{|c|c|c|c|}
\hline $\begin{array}{l}\text { Economic } \\
\text { Sector }\end{array}$ & Profession & $\begin{array}{c}\text { Father } \\
(N=101)\end{array}$ & $\begin{array}{l}\text { Mother } \\
(N=101)\end{array}$ \\
\hline \multirow[t]{3}{*}{ Primary } & Farmer & 4 & - \\
\hline & Shepherd & - & 1 \\
\hline & $N($ total $)=5(2.48 \%)$ & $4(3.96 \%)$ & $1(0.99 \%)$ \\
\hline \multirow[t]{3}{*}{ Secondary } & Nursing technician, Nursing assistant & 0 & 1 \\
\hline & Office assistant, Administrative assistant, Laboratory assistant & 1 & 1 \\
\hline & $N($ total $)=3(1.49 \%)$ & $1(0.99 \%)$ & $2(1.98 \%)$ \\
\hline \multirow[t]{22}{*}{ Tertiary } & Dentist or Orthodontist & 2 & 7 \\
\hline & Lawyer, Public prosecutor, Civil servant (federal, state and municipal) & 31 & 27 \\
\hline & Business administrator & 5 & 4 \\
\hline & Architect, Artist & 1 & 3 \\
\hline & Banker & 2 & 2 \\
\hline & Accountant & 3 & - \\
\hline & Systems analyst & 2 & 1 \\
\hline & Economist & 5 & 2 \\
\hline & Photographer & 1 & - \\
\hline & Manager & 4 & - \\
\hline & Nutritionist, Psychologist, Pharmacist, Doctor & 3 & 5 \\
\hline & Teacher & 1 & 21 \\
\hline & Cook & 3 & - \\
\hline & Truck driver & 3 & - \\
\hline & Trader & 6 & 3 \\
\hline & Sales representative & 6 & - \\
\hline & Salesman & 2 & 2 \\
\hline & City councilor & 1 & - \\
\hline & Businessman & 9 & 3 \\
\hline & Referee & 1 & - \\
\hline & Receptionist, Secretary & - & 1 \\
\hline & $N=172(85.15 \%)$ & $91(90.1 \%)$ & $81(80.2 \%)$ \\
\hline \multirow[t]{2}{*}{ Do not work } & Homemaker & - & 15 \\
\hline & $N=15(7.43 \%)$ & $0(0 \%)$ & $15(14.85 \%)$ \\
\hline \multirow[t]{3}{*}{ Others } & Deceased & 5 & 2 \\
\hline & $N=7(3.47 \%)$ & $5(4.95 \%)$ & $2(1.98 \%)$ \\
\hline & $N($ Total) $202=(100 \%)$ & $101(100 \%)$ & $101(100 \%)$ \\
\hline
\end{tabular}


Therefore, $2.48 \%$ of the parents of the children from private schools work in the primary sector, $1.49 \%$ work in the secondary sector and $85.15 \%$ work in the tertiary sector, while the majority of these parents work in services. Non-working parents make up $7.43 \%$, all of whom are the mothers. A minority of $3.47 \%$ make up the group of deceased parents.

Table 5

Relation of Economic Sectors with the Occupation of Public School Parents

\begin{tabular}{|c|c|c|c|}
\hline $\begin{array}{l}\text { Economic } \\
\text { Sector }\end{array}$ & Profession & $\begin{array}{c}\text { Father } \\
(N=110)\end{array}$ & $\begin{array}{l}\text { Mother } \\
(N=110)\end{array}$ \\
\hline \multirow[t]{2}{*}{ Primary } & Shepherd & 1 & 1 \\
\hline & $N($ total $)=2(.90 \%)$ & $1(0.90 \%)$ & $1(0.90 \%)$ \\
\hline \multirow[t]{9}{*}{ Secondary } & Builder, Electrician, Painter, Metalworker & 12 & - \\
\hline & Carpenter & 2 & - \\
\hline & Mechanic, Solder, Auto body worker & 10 & - \\
\hline & Seamstress & - & 2 \\
\hline & $\begin{array}{l}\text { Stocktaker, Assembler, Packer, Unloader, Gas station } \\
\text { attendant. Fisherman }\end{array}$ & & 0 \\
\hline & Computer technician, Typist & $\begin{array}{c}21 \\
6\end{array}$ & 1 \\
\hline & Nursing technician, Nursing assistant & 2 & 2 \\
\hline & Office assistant, Administrative assistant, Laboratory assistant & 3 & 5 \\
\hline & $N($ total $)=75(34.1 \%)$ & $56(50.9 \%)$ & $19(17.27 \%)$ \\
\hline \multirow[t]{16}{*}{ Tertiary } & Municipal civil servant & 1 & - \\
\hline & Accountant & - & 2 \\
\hline & Photographer & - & 1 \\
\hline & Teacher & - & 4 \\
\hline & Bus conductor, Checkout operator & 3 & 1 \\
\hline & $\begin{array}{l}\text { Domestic worker, Cleaner, Chambermaid, Cook, Kitchen } \\
\text { assistant, Car wash worker }\end{array}$ & - & 19 \\
\hline & Chauffeur, Delivery driver, Taxi driver, Truck driver & 11 & - \\
\hline & Manicurist, Hairdresser & - & 4 \\
\hline & Doorman, Security guard & 4 & - \\
\hline & Trader & 8 & 7 \\
\hline & Real estate agent, Insurance agent & 2 & - \\
\hline & Sales representative & 5 & 3 \\
\hline & Salesman & 13 & 14 \\
\hline & Referee & 2 & - \\
\hline & Receptionist, Secretary & - & 6 \\
\hline & $N=110(50 \%)$ & $49(44.6 \%)$ & $61(55.5 \%)$ \\
\hline \multirow[t]{2}{*}{ Do not work } & Homemaker & - & 27 \\
\hline & $N=27(12.27 \%)$ & $0(0 \%)$ & $27(24.5 \%)$ \\
\hline \multirow[t]{3}{*}{ Others } & Deceased or don't know & 4 & 2 \\
\hline & $N=6(2.73 \%)$ & $4(3.63 \%)$ & $2(1.81 \%)$ \\
\hline & $N($ Total $) 220=(100 \%)$ & $110(100 \%)$ & $110(100 \%)$ \\
\hline
\end{tabular}

Therefore, $.90 \%$ of the parents of the children from public schools work in the primary sector, $34.1 \%$ work in the secondary sector and $50.0 \%$ work in the tertiary sector, while the majority of these parents work in services. Non-working parents make up $12.27 \%$, all of whom are the mothers. A minority of $2.73 \%$ make up the group of deceased parents or those who did not know the profession of the parents, since the respondent of the CBCL had no contact with the child's mother or father. 
Tables 6 and 7 show with whom the children was living at the time of the assessment, Table 6 for the children from private schools and Table 7 for the children from public schools.

Table 6

With whom the Children from Private School were Living at the Time of the Assessment

\begin{tabular}{lcr}
\hline With whom the children live & $N(101)$ & $\%$ \\
\hline Parents & 78 & 77.2 \\
Mother & 22 & 21.8 \\
Father & 1 & 1.0 \\
Others & 0 & 0.0 \\
\hline
\end{tabular}

The data show that $77.2 \%$ of the children from private schools were living with their biological parents at the time of the assessment. Of those who were living with only one of their biological parents, $21.8 \%$ were living with their mother and $1 \%$ with their father.

Table 7

With whom the Children from Public School were Living at the Time of the Assessment

\begin{tabular}{lcr}
\hline With whom the children live & $N(110)$ & $\%$ \\
\hline Parents & 66 & 60.0 \\
Mother & 40 & 36.4 \\
Father & 0 & 0.0 \\
Others & 4 & 3.6 \\
\hline
\end{tabular}

The data show that $60 \%$ of the children from public schools were living with their biological parents at the time of the assessment. Of those who were living with only one of their biological parents, $36.4 \%$ were living with their mother. Only $3.6 \%$ of the sample total were living with grandparents or uncles and aunts.

\section{Results}

The data permitted the construction of reference tables by age group and school origin for the 113 Rorschach variables, for children aged 7-10 of both genders from public and private schools, defining and determining the Rorschach assessment categories in accordance with statistical criteria ${ }^{1}$. It was decided to compile separate tables by age group, since a grouping of the ages could lead to a distortion of the results in the variables. An interrater reliability study was conducted, in accordance with Table 8, with the basic scores for each response.
Table 8

Brazilian Children Sample Reliability data $(n=52)$

\begin{tabular}{lrr}
\hline Variables & $\begin{array}{r}\% \\
\text { Agreement }\end{array}$ & $\begin{array}{r}\text { Cohen's } \\
\text { Kappa }\end{array}$ \\
\hline Location \& Spaces & .97 & .81 \\
$D Q$ & 1.00 & 1.00 \\
Determinants (14 variables) & .94 & .68 \\
$F Q$ & .87 & .65 \\
Pairs & .99 & .97 \\
Contents (25 variables) & .94 & .84 \\
$P$ & .89 & .97 \\
$Z$ Scores & .99 & .97 \\
$C S$ Special Scores & .94 & .79 \\
\hline
\end{tabular}

According to the results, the coefficient varied between .65 and .97 , i.e., agreements ranging from medium to excellent. The interrater agreement percentage was higher than $90 \%$ in practically all the variables, with the exception of the $F Q$ and Determinant variables.

The descriptive data for the Rorschach Comprehensive System variables were separated into tables according to age group and school origin. The descriptive statistics of these variables were calculated and they are presented in the following two tables: Table 9 - children from private schools $(N=101)$ and Table 10 - children from public schools $(N=110)$.

Comparative statistical analyses were conducted between the groups of children from private schools $(N=101)$ and public schools $(N=110)$. The results according to the " $t$-test", with a level of significance $(p<.05)$ and the Bonferroni correction, revealed some significant statistical differences. The Bonferroni correction was the chosen methodology because it can deal with situations in which several comparisons are made within a single sample. The assumed parametrics of homogeneity of variances were contrasted (Levene's test) to perform the Student's $t$-test. That is, verification was made of the cases in which the variances assumed as being equal were confirmed using Levene's test and the cases in which this did not occur (and the variances were not assumed to be equal). This being the case, since the data were run through SPSS software, the Levene's test is the most standard means for the t-test in independent samples. The children from private schools presented higher results in the $R$, Sum $Y$ and Blends variables and in the Intellectualization Index than the children from public schools, who presented higher results in the Lambda variable.

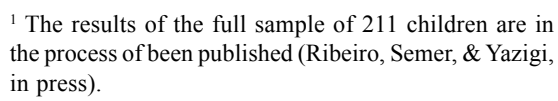

${ }^{1}$ The results of the full sample of 211 children are in the process of been published (Ribeiro, Semer, \& Yazigi, in press). 
Ribeiro, R. K. S. M., Semer, N. L. \& Yazigi, L. (2011). Rorschach Comprehensive System Norms in Brazilian Children from Public and Private Schools.

Table 9

Statistical Distribution of the 113 Rorschach Variables of Children from Private Schools $(N=101)$

\begin{tabular}{|c|c|c|c|c|c|c|c|c|}
\hline \multirow[t]{2}{*}{ Variables } & \multicolumn{2}{|c|}{7 year olds $(N=27)$} & \multicolumn{2}{|c|}{8 year olds $(N=29)$} & \multicolumn{2}{|c|}{9 year olds $(N=23)$} & \multicolumn{2}{|c|}{10 year olds $(N=22)$} \\
\hline & $M$ & $S D$ & $M$ & $S D$ & $M$ & $S D$ & $M$ & $S D$ \\
\hline $\mathrm{R}$ & 16.56 & 3.07 & 17.38 & 4.39 & 16.09 & 2.78 & 18.45 & 5.25 \\
\hline W & 5.22 & 2.81 & 4.86 & 3.06 & 4.65 & 2.87 & 4.55 & 2.39 \\
\hline $\mathrm{D}$ & 8.56 & 3.19 & 8.38 & 4.77 & 8.26 & 3.45 & 9.77 & 4.48 \\
\hline $\mathrm{Dd}$ & 2.78 & 2.75 & 4.14 & 2.81 & 3.17 & 2.21 & 4.14 & 3.01 \\
\hline $\mathrm{S}$ & 1.19 & 1.27 & 1.17 & 1.26 & 1.00 & 1.04 & 1.95 & 1.33 \\
\hline $\mathrm{DQ}^{+}$ & 2.37 & 2.40 & 3.07 & 2.33 & 4.22 & 2.41 & 3.23 & 2.78 \\
\hline DQo & 13.41 & 4.12 & 13.38 & 4.60 & 11.13 & 3.76 & 14.05 & 5.51 \\
\hline DQv & 0.59 & 1.05 & 0.83 & 1.14 & 0.48 & 0.73 & 0.91 & 1.02 \\
\hline DQv/+ & 0.19 & 0.40 & 0.10 & 0.31 & 0.26 & 0.54 & 0.27 & 0.55 \\
\hline $\mathrm{FQx}+$ & 0.00 & 0.00 & 0.00 & 0.00 & 0.04 & 0.21 & 0.00 & 0.00 \\
\hline FQxo & 6.26 & 1.56 & 6.97 & 2.80 & 7.13 & 1.82 & 6.77 & 2.93 \\
\hline FQxu & 4.00 & 1.71 & 3.52 & 2.15 & 3.35 & 1.56 & 4.64 & 2.57 \\
\hline FQx- & 5.89 & 2.93 & 6.69 & 2.69 & 5.43 & 2.71 & 6.86 & 2.40 \\
\hline FQxnone & 0.41 & 0.89 & 0.21 & 0.41 & 0.13 & 0.34 & 0.18 & 0.39 \\
\hline MQual + & 0.00 & 0.00 & 0.00 & 0.00 & 0.04 & 0.21 & 0.00 & 0.00 \\
\hline MQual o & 0.30 & 0.54 & 0.69 & 0.76 & 0.70 & 0.70 & 0.45 & 0.67 \\
\hline MQual u & 0.11 & 0.32 & 0.14 & 0.35 & 0.30 & 0.70 & 0.45 & 0.60 \\
\hline MQual - & 0.22 & 0.64 & 0.34 & 0.55 & 0.65 & 1.03 & 0.50 & 0.67 \\
\hline MQual none & 0.00 & 0.00 & 0.00 & 0.00 & 0.00 & 0.00 & 0.00 & 0.00 \\
\hline SQual- & 0.52 & 0.75 & 0.69 & 0.71 & 0.61 & 0.78 & 1.18 & 1.10 \\
\hline M & 0.63 & 1.08 & 1.17 & 1.00 & 1.70 & 1.72 & 1.41 & 1.37 \\
\hline FM & 1.89 & 2.12 & 2.14 & 1.71 & 2.39 & 1.67 & 2.27 & 2.07 \\
\hline $\mathrm{m}$ & 0.52 & 1.01 & 1.00 & 1.20 & 0.91 & 1.16 & 1.23 & 1.38 \\
\hline $\mathrm{FC}$ & 0.70 & 1.14 & 0.41 & 0.68 & 0.22 & 0.42 & 0.59 & 0.80 \\
\hline $\mathrm{CF}$ & 0.81 & 1.11 & 1.00 & 1.07 & 0.61 & 0.66 & 0.91 & 1.06 \\
\hline $\mathrm{C}$ & 0.48 & 0.89 & 0.66 & 0.86 & 0.61 & 0.84 & 0.59 & 0.85 \\
\hline $\mathrm{Cn}$ & 0.00 & 0.00 & 0.00 & 0.00 & 0.00 & 0.00 & 0.00 & 0.00 \\
\hline Sum C & 2.00 & 1.90 & 2.07 & 1.62 & 1.43 & 1.24 & 2.09 & 1.80 \\
\hline WSum C & 1.89 & 1.85 & 2.19 & 1.76 & 1.63 & 1.55 & 2.09 & 2.03 \\
\hline $\mathrm{FC}^{\prime}$ & 0.26 & 0.45 & 0.03 & 0.19 & 0.26 & 0.69 & 0.32 & 0.57 \\
\hline$C^{\prime} F$ & 0.07 & 0.27 & 0.21 & 0.41 & 0.00 & 0.00 & 0.14 & 0.47 \\
\hline $\mathrm{C}^{\prime}$ & 0.11 & 0.42 & 0.00 & 0.00 & 0.04 & 0.21 & 0.14 & 0.35 \\
\hline FT & 0.22 & 0.70 & 0.07 & 0.26 & 0.17 & 0.39 & 0.41 & 1.10 \\
\hline $\mathrm{TF}$ & 0.00 & 0.00 & 0.00 & 0.00 & 0.04 & 0.21 & 0.00 & 0.00 \\
\hline $\mathrm{T}$ & 0.00 & 0.00 & 0.00 & 0.00 & 0.00 & 0.00 & 0.00 & 0.00 \\
\hline FV & 0.11 & 0.32 & 0.14 & 0.44 & 0.09 & 0.29 & 0.14 & 0.47 \\
\hline $\mathrm{VF}$ & 0.00 & 0.00 & 0.00 & 0.00 & 0.00 & 0.00 & 0.05 & 0.21 \\
\hline $\mathrm{V}$ & 0.00 & 0.00 & 0.00 & 0.00 & 0.00 & 0.00 & 0.00 & 0.00 \\
\hline FY & 0.85 & 1.10 & 0.90 & 1.08 & 0.87 & 1.01 & 1.05 & 1.05 \\
\hline YF & 0.15 & 0.46 & 0.07 & 0.26 & 0.26 & 0.45 & 0.14 & 0.47 \\
\hline Y & 0.04 & 0.19 & 0.00 & 0.00 & 0.13 & 0.46 & 0.05 & 0.21 \\
\hline $\mathrm{Fr}$ & 0.11 & 0.32 & 0.03 & 0.19 & 0.13 & 0.34 & 0.18 & 0.50 \\
\hline $\mathrm{rF}$ & 0.00 & 0.00 & 0.00 & 0.00 & 0.00 & 0.00 & 0.00 & 0.00 \\
\hline Sum C' & 0.44 & 0.89 & 0.24 & 0.44 & 0.30 & 0.70 & 0.59 & 1.10 \\
\hline Sum T & 0.22 & 0.70 & 0.07 & 0.26 & 0.22 & 0.42 & 0.41 & 1.10 \\
\hline Sum V & 0.11 & 0.32 & 0.14 & 0.44 & 0.09 & 0.29 & 0.18 & 0.50 \\
\hline Sum Y & 1.04 & 1.26 & 0.97 & 1.05 & 1.26 & 1.32 & 1.23 & 0.97 \\
\hline Sum Shading & 1.81 & 1.52 & 1.41 & 1.24 & 1.87 & 1.79 & 2.41 & 2.34 \\
\hline $\mathrm{Fr}+\mathrm{rF}$ & 0.11 & 0.32 & 0.03 & 0.19 & 0.13 & 0.34 & 0.18 & 0.50 \\
\hline
\end{tabular}


(Continuation of the Table 9)

Statistical Distribution of the 113 Rorschach Variables of Children from Private Schools $(N=101)$

\begin{tabular}{|c|c|c|c|c|c|c|c|c|}
\hline \multirow[t]{2}{*}{ Variables } & \multicolumn{2}{|c|}{7 year olds $(N=27)$} & \multicolumn{2}{|c|}{8 year olds $(N=29)$} & \multicolumn{2}{|c|}{9 year olds $(N=23)$} & \multicolumn{2}{|c|}{10 year olds $(N=22)$} \\
\hline & $M$ & $S D$ & $M$ & $S D$ & $M$ & $S D$ & $M$ & $S D$ \\
\hline FD & 0.22 & 0.42 & 0.38 & 0.73 & 0.52 & 0.73 & 0.73 & 0.88 \\
\hline $\mathrm{F}$ & 10.59 & 3.65 & 11.14 & 4.06 & 8.87 & 3.85 & 10.45 & 4.48 \\
\hline Pair & 3.85 & 2.76 & 5.00 & 3.46 & 5.04 & 2.62 & 4.32 & 3.93 \\
\hline $3 r+(2) / R$ & 0.25 & 0.17 & 0.29 & 0.17 & 0.34 & 0.21 & 0.26 & 0.21 \\
\hline Lambda & 2.70 & 2.85 & 3.24 & 3.86 & 2.05 & 2.14 & 2.16 & 3.12 \\
\hline PureF\% & 0.64 & 0.17 & 0.64 & 0.18 & 0.55 & 0.21 & 0.56 & 0.19 \\
\hline $\mathrm{FM}+\mathrm{m}$ & 2.41 & 2.56 & 3.14 & 2.22 & 3.30 & 2.14 & 3.50 & 2.65 \\
\hline EA & 2.52 & 2.23 & 3.36 & 2.17 & 3.33 & 2.81 & 3.50 & 2.41 \\
\hline es & 4.22 & 3.17 & 4.55 & 2.82 & 5.17 & 3.38 & 5.91 & 3.44 \\
\hline D Score & -0.37 & 1.15 & -0.28 & 0.70 & -0.43 & 0.90 & -0.68 & 0.99 \\
\hline Adj D & -0.19 & 1.08 & -0.14 & 0.64 & -0.17 & 0.78 & -0.36 & 0.90 \\
\hline a (active) & 2.04 & 2.44 & 2.93 & 2.12 & 3.48 & 2.74 & 2.91 & 2.41 \\
\hline p (passive) & 1.00 & 1.18 & 1.41 & 1.21 & 1.57 & 1.56 & 2.05 & 1.73 \\
\hline $\mathrm{Ma}$ & 0.30 & 0.47 & 0.69 & 0.89 & 1.17 & 1.40 & 0.91 & 1.15 \\
\hline $\mathrm{Mp}$ & 0.33 & 0.92 & 0.45 & 0.57 & 0.48 & 0.73 & 0.50 & 0.60 \\
\hline Intellect & 0.81 & 0.83 & 0.62 & 0.78 & 1.09 & 1.04 & 0.91 & 1.02 \\
\hline $\mathrm{Zf}$ & 6.78 & 3.17 & 6.93 & 2.94 & 7.70 & 3.05 & 7.41 & 3.20 \\
\hline $\mathrm{Zd}$ & 0.09 & 2.35 & -0.22 & 3.78 & -1.02 & 2.41 & 0.02 & 2.80 \\
\hline Blends & 1.15 & 1.51 & 1.90 & 1.63 & 1.52 & 1.95 & 1.95 & 1.68 \\
\hline Blends/R & 0.07 & 0.09 & 0.11 & 0.10 & 0.09 & 0.12 & 0.11 & 0.11 \\
\hline Col.Shd Blends & 0.07 & 0.27 & 0.03 & 0.19 & 0.04 & 0.21 & 0.18 & 0.39 \\
\hline Afr & 0.55 & 0.23 & 0.61 & 0.22 & 0.52 & 0.23 & 0.55 & 0.16 \\
\hline Popular & 3.04 & 1.19 & 3.17 & 1.47 & 4.04 & 1.33 & 3.23 & 1.31 \\
\hline $\mathrm{XA} \%$ & 0.63 & 0.12 & 0.60 & 0.15 & 0.66 & 0.14 & 0.61 & 0.12 \\
\hline WDA\% & 0.70 & 0.12 & 0.71 & 0.16 & 0.74 & 0.16 & 0.73 & 0.11 \\
\hline $\mathrm{X}+\%$ & 0.39 & 0.11 & 0.40 & 0.13 & 0.45 & 0.11 & 0.36 & 0.11 \\
\hline $\mathrm{X}-\%$ & 0.35 & 0.12 & 0.39 & 0.15 & 0.33 & 0.14 & 0.38 & 0.12 \\
\hline $\mathrm{Xu} \%$ & 0.24 & 0.08 & 0.20 & 0.11 & 0.21 & 0.10 & 0.25 & 0.10 \\
\hline Isolate/ $\mathrm{R}$ & 0.17 & 0.17 & 0.18 & 0.17 & 0.16 & 0.18 & 0.17 & 0.16 \\
\hline $\mathrm{H}$ & 1.15 & 1.29 & 1.31 & 1.20 & 1.83 & 1.61 & 1.45 & 1.68 \\
\hline$(\mathrm{H})$ & 0.63 & 0.88 & 0.55 & 0.63 & 0.87 & 1.01 & 0.59 & 0.80 \\
\hline $\mathrm{Hd}$ & 0.63 & 0.69 & 1.38 & 1.97 & 1.26 & 1.42 & 1.05 & 1.13 \\
\hline$(\mathrm{Hd})$ & 0.19 & 0.56 & 0.21 & 0.41 & 0.17 & 0.39 & 0.55 & 0.74 \\
\hline $\mathrm{Hx}$ & 0.04 & 0.19 & 0.10 & 0.31 & 0.17 & 0.39 & 0.14 & 0.35 \\
\hline $\mathrm{H}+(\mathrm{H})+\mathrm{Hd}+(\mathrm{Hd})$ & 2.59 & 1.95 & 3.45 & 2.43 & 4.13 & 2.40 & 3.64 & 2.13 \\
\hline$(\mathrm{H})+\mathrm{Hd}+(\mathrm{Hd})$ & 1.44 & 1.34 & 2.14 & 1.90 & 2.30 & 1.64 & 2.18 & 1.65 \\
\hline A & 8.74 & 3.55 & 8.45 & 3.56 & 7.39 & 2.76 & 8.09 & 3.52 \\
\hline (A) & 0.19 & 0.40 & 0.38 & 0.73 & 0.17 & 0.39 & 0.23 & 0.43 \\
\hline Ad & 1.63 & 1.90 & 1.76 & 1.94 & 1.43 & 1.41 & 2.27 & 2.00 \\
\hline$(\mathrm{Ad})$ & 0.07 & 0.27 & 0.03 & 0.19 & 0.04 & 0.21 & 0.14 & 0.35 \\
\hline An & 0.74 & 1.20 & 0.52 & 0.74 & 0.78 & 1.00 & 0.55 & 0.80 \\
\hline Art & 0.78 & 0.80 & 0.62 & 0.78 & 0.78 & 0.52 & 0.68 & 0.95 \\
\hline Ay & 0.04 & 0.19 & 0.00 & 0.00 & 0.13 & 0.46 & 0.14 & 0.35 \\
\hline $\mathrm{Bl}$ & 0.04 & 0.19 & 0.17 & 0.47 & 0.17 & 0.39 & 0.14 & 0.47 \\
\hline $\mathrm{Bt}$ & 0.56 & 0.80 & 0.52 & 1.06 & 0.35 & 0.57 & 0.95 & 0.90 \\
\hline $\mathrm{Cg}$ & 0.93 & 0.92 & 1.00 & 1.13 & 1.43 & 1.38 & 1.14 & 1.08 \\
\hline $\mathrm{Cl}$ & 0.00 & 0.00 & 0.07 & 0.26 & 0.00 & 0.00 & 0.14 & 0.35 \\
\hline Ex & 0.00 & 0.00 & 0.07 & 0.26 & 0.04 & 0.21 & 0.09 & 0.29 \\
\hline
\end{tabular}


Ribeiro, R. K. S. M., Semer, N. L. \& Yazigi, L. (2011). Rorschach Comprehensive System Norms in Brazilian Children from Public and Private Schools.

(Continuation of the Table 9)

Statistical Distribution of the 113 Rorschach Variables of Children from Private Schools $(N=101)$

\begin{tabular}{|c|c|c|c|c|c|c|c|c|}
\hline \multirow[t]{2}{*}{ Variables } & \multicolumn{2}{|c|}{7 year olds $(N=27)$} & \multicolumn{2}{|c|}{8 year olds $(N=29)$} & \multicolumn{2}{|c|}{9 year olds $(N=23)$} & \multicolumn{2}{|c|}{10 year olds $(N=22)$} \\
\hline & $M$ & $S D$ & $M$ & $S D$ & $M$ & $S D$ & $M$ & $S D$ \\
\hline $\mathrm{Fi}$ & 0.15 & 0.46 & 0.52 & 0.78 & 0.26 & 0.69 & 0.41 & 0.73 \\
\hline $\mathrm{Fd}$ & 0.07 & 0.38 & 0.28 & 0.70 & 0.26 & 0.54 & 0.05 & 0.21 \\
\hline $\mathrm{Ge}$ & 0.11 & 0.42 & 0.03 & 0.19 & 0.09 & 0.29 & 0.05 & 0.21 \\
\hline $\mathrm{Hh}$ & 0.07 & 0.27 & 0.28 & 0.65 & 0.17 & 0.39 & 0.23 & 0.53 \\
\hline Ls & 0.00 & 0.00 & 0.28 & 0.53 & 0.17 & 0.39 & 0.41 & 0.80 \\
\hline $\mathrm{Na}$ & 1.00 & 1.07 & 1.07 & 1.19 & 0.96 & 1.26 & 0.82 & 1.26 \\
\hline $\mathrm{Sc}$ & 0.44 & 0.80 & 0.83 & 1.42 & 0.78 & 1.38 & 0.95 & 1.13 \\
\hline Sx & 0.00 & 0.00 & 0.03 & 0.19 & 0.13 & 0.46 & 0.00 & 0.00 \\
\hline Xy & 0.00 & 0.00 & 0.03 & 0.19 & 0.00 & 0.00 & 0.05 & 0.21 \\
\hline Id & 0.63 & 0.88 & 0.45 & 0.63 & 0.70 & 0.82 & 0.77 & 0.97 \\
\hline$A n+X y$ & 0.74 & 1.20 & 0.55 & 0.78 & 0.78 & 1.00 & 0.59 & 0.91 \\
\hline DV & 0.44 & 0.80 & 0.31 & 0.47 & 0.22 & 0.42 & 0.59 & 0.73 \\
\hline INCOM & 0.30 & 0.54 & 0.59 & 0.82 & 0.22 & 0.42 & 0.45 & 0.67 \\
\hline DR & 0.11 & 0.32 & 0.14 & 0.35 & 0.17 & 0.49 & 0.14 & 0.64 \\
\hline FABCOM & 0.19 & 0.48 & 0.14 & 0.35 & 0.39 & 0.58 & 0.18 & 0.50 \\
\hline DV2 & 0.00 & 0.00 & 0.00 & 0.00 & 0.00 & 0.00 & 0.00 & 0.00 \\
\hline INCOM2 & 0.00 & 0.00 & 0.07 & 0.26 & 0.00 & 0.00 & 0.09 & 0.29 \\
\hline DR2 & 0.00 & 0.00 & 0.00 & 0.00 & 0.00 & 0.00 & 0.00 & 0.00 \\
\hline FABCOM2 & 0.11 & 0.58 & 0.00 & 0.00 & 0.04 & 0.21 & 0.14 & 0.35 \\
\hline ALOG & 0.00 & 0.00 & 0.03 & 0.19 & 0.00 & 0.00 & 0.00 & 0.00 \\
\hline CONTAM & 0.04 & 0.19 & 0.03 & 0.19 & 0.00 & 0.00 & 0.00 & 0.00 \\
\hline Sum6 Sp Sc & 1.19 & 1.94 & 1.31 & 1.26 & 1.04 & 1.11 & 1.59 & 1.59 \\
\hline Lvl $2 \mathrm{Sp} \mathrm{Sc}$ & 0.11 & 0.58 & 0.07 & 0.26 & 0.04 & 0.21 & 0.23 & 0.43 \\
\hline WSum6 & 3.15 & 7.33 & 3.14 & 3.24 & 3.04 & 3.88 & 3.95 & 5.25 \\
\hline $\mathrm{AB}$ & 0.00 & 0.00 & 0.00 & 0.00 & 0.09 & 0.29 & 0.05 & 0.21 \\
\hline $\mathrm{AG}$ & 0.19 & 0.40 & 0.34 & 0.61 & 0.22 & 0.52 & 0.45 & 0.80 \\
\hline $\mathrm{COP}$ & 0.15 & 0.46 & 0.24 & 0.44 & 0.52 & 0.90 & 0.27 & 0.46 \\
\hline $\mathrm{CP}$ & 0.04 & 0.19 & 0.03 & 0.19 & 0.00 & 0.00 & 0.00 & 0.00 \\
\hline Good HR & 1.44 & 1.60 & 1.41 & 1.02 & 2.13 & 1.39 & 1.82 & 1.53 \\
\hline Poor HR & 1.33 & 1.00 & 2.28 & 2.10 & 2.35 & 1.77 & 2.27 & 1.35 \\
\hline MOR & 0.15 & 0.36 & 0.31 & 0.85 & 0.48 & 0.73 & 0.23 & 0.43 \\
\hline PER & 0.63 & 1.60 & 0.14 & 0.44 & 0.48 & 0.79 & 0.32 & 0.57 \\
\hline PSV & 0.19 & 0.48 & 0.17 & 0.38 & 0.04 & 0.21 & 0.14 & 0.35 \\
\hline PTI Total & 1.59 & 1.34 & 1.52 & 1.24 & 1.35 & 1.37 & 1.68 & 1.25 \\
\hline DEPI Total & 3.26 & 1.02 & 3.24 & 0.83 & 2.87 & 0.97 & 3.32 & 1.04 \\
\hline CDI Total & 3.63 & 0.69 & 3.55 & 1.02 & 3.48 & 0.95 & 3.23 & 1.02 \\
\hline SCON Total & 4.67 & 1.36 & 5.17 & 1.44 & 4.57 & 1.20 & 4.91 & 1.77 \\
\hline HVI Total & 1.56 & 0.85 & 1.86 & 1.09 & 1.74 & 0.96 & 2.09 & 0.97 \\
\hline OBS Total (1-5) & 0.33 & 0.62 & 0.69 & 0.60 & 0.43 & 0.51 & 0.64 & 0.49 \\
\hline WD+ & 0.00 & 0.00 & 0.00 & 0.00 & 0.04 & 0.21 & 0.00 & 0.00 \\
\hline WDo & 6.19 & 1.55 & 6.66 & 2.78 & 6.70 & 1.58 & 6.73 & 2.86 \\
\hline WDu & 3.44 & 1.60 & 2.79 & 1.92 & 2.57 & 1.38 & 3.73 & 2.10 \\
\hline WD- & 3.81 & 1.86 & 3.62 & 1.95 & 3.52 & 2.69 & 3.68 & 1.73 \\
\hline WDNone & 0.33 & 0.78 & 0.17 & 0.38 & 0.09 & 0.29 & 0.18 & 0.39 \\
\hline EII_2 & 0.00 & 0.59 & 0.26 & 0.61 & 0.17 & 0.85 & 0.22 & 0.60 \\
\hline HRV & 0.11 & 1.55 & -0.86 & 2.20 & -0.22 & 2.15 & -0.45 & 2.09 \\
\hline
\end{tabular}


Psicologia: Reflexão e Crítica, 24(4), 671-684.

Table 10

Statistical Distribution of the 113 Rorschach Variables of Children from Public Schools $(N=101)$

\begin{tabular}{|c|c|c|c|c|c|c|c|c|}
\hline \multirow[t]{2}{*}{ Variables } & \multicolumn{2}{|c|}{7 year olds $(N=23)$} & \multicolumn{2}{|c|}{8 year olds $(N=24)$} & \multicolumn{2}{|c|}{9 year olds $(N=30)$} & \multicolumn{2}{|c|}{10 year olds $(N=33)$} \\
\hline & $M$ & $S D$ & $M$ & $S D$ & $M$ & $S D$ & $M$ & $S D$ \\
\hline$R$ & 15.09 & 1.51 & 15.63 & 2.08 & 16.13 & 2.97 & 15.61 & 1.56 \\
\hline$W$ & 5.13 & 3.12 & 5.50 & 2.59 & 3.20 & 2.38 & 4.48 & 2.71 \\
\hline$D$ & 6.70 & 2.48 & 7.17 & 3.52 & 8.97 & 2.77 & 7.79 & 2.72 \\
\hline $\mathrm{Dd}$ & 3.26 & 2.12 & 2.96 & 2.49 & 3.97 & 2.33 & 3.33 & 2.45 \\
\hline $\mathrm{S}$ & 1.04 & 1.07 & 1.21 & 1.28 & 1.17 & 1.12 & 1.30 & 1.07 \\
\hline $\mathrm{DQ}^{+}$ & 1.35 & 1.40 & 2.33 & 2.57 & 2.40 & 2.70 & 2.58 & 2.56 \\
\hline DQo & 12.61 & 2.15 & 12.54 & 2.95 & 13.10 & 3.39 & 12.61 & 2.96 \\
\hline DQv & 1.04 & 1.82 & 0.67 & 1.01 & 0.57 & 1.04 & 0.39 & .83 \\
\hline DQv/+ & 0.09 & 0.29 & 0.08 & 0.28 & 0.07 & 0.25 & 0.03 & .17 \\
\hline $\mathrm{FQx}+$ & 0.00 & 0.00 & 0.00 & 0.00 & 0.03 & 0.18 & 0.03 & .17 \\
\hline FQxo & 5.39 & 2.02 & 5.79 & 2.23 & 6.40 & 1.59 & 6.79 & 2.25 \\
\hline FQxu & 3.48 & 1.62 & 3.79 & 2.48 & 4.27 & 2.53 & 3.58 & 1.90 \\
\hline FQx- & 5.70 & 2.14 & 5.67 & 2.10 & 5.20 & 1.94 & 5.03 & 2.31 \\
\hline FQxnone & 0.52 & 0.79 & 0.38 & 0.77 & 0.23 & 0.43 & 0.18 & 0.64 \\
\hline MQual + & 0.00 & 0.00 & 0.00 & 0.00 & 0.03 & 0.18 & 0.00 & 0.00 \\
\hline MQual o & 0.04 & 0.21 & 0.21 & 0.51 & 0.37 & 0.72 & 0.76 & 0.97 \\
\hline MQual u & 0.04 & 0.21 & 0.29 & 0.69 & 0.30 & 0.79 & 0.15 & 0.36 \\
\hline MQual - & 0.17 & 0.49 & 0.13 & 0.34 & 0.33 & 0.48 & 0.33 & 0.69 \\
\hline MQual none & 0.00 & 0.00 & 0.00 & 0.00 & 0.03 & 0.18 & 0.00 & 0.00 \\
\hline SQual- & 0.61 & 0.94 & 0.75 & 0.99 & 0.47 & 0.78 & 0.70 & 0.73 \\
\hline $\mathrm{M}$ & 0.26 & 0.54 & 0.63 & 1.01 & 1.07 & 1.48 & 1.24 & 1.39 \\
\hline FM & 1.09 & 1.12 & 1.79 & 1.64 & 1.67 & 1.79 & 1.79 & 1.49 \\
\hline $\mathrm{m}$ & 0.43 & 0.73 & 0.54 & 1.18 & 0.53 & 0.86 & 0.64 & 0.99 \\
\hline $\mathrm{FC}$ & 0.13 & 0.34 & 0.46 & 0.59 & 0.13 & 0.35 & 0.24 & 0.56 \\
\hline $\mathrm{CF}$ & 0.91 & 1.56 & 0.58 & 1.06 & 0.43 & 0.63 & 0.21 & 0.42 \\
\hline $\mathrm{C}$ & 0.70 & 1.15 & 0.50 & 0.93 & 0.33 & 0.71 & 0.30 & 0.68 \\
\hline $\mathrm{Cn}$ & 0.00 & 0.00 & 0.00 & 0.00 & 0.00 & 0.00 & 0.00 & 0.00 \\
\hline Sum C & 1.74 & 2.34 & 1.54 & 1.50 & 0.90 & 1.09 & 0.76 & 1.00 \\
\hline WSum C & 2.02 & 2.78 & 1.56 & 1.72 & 1.00 & 1.37 & 0.79 & 1.16 \\
\hline $\mathrm{FC}^{\prime}$ & 0.13 & 0.34 & 0.25 & 0.44 & 0.27 & 0.64 & 0.21 & 0.48 \\
\hline$C^{\prime} F$ & 0.22 & 0.52 & 0.08 & 0.28 & 0.07 & 0.25 & 0.03 & 0.17 \\
\hline$C^{\prime}$ & 0.17 & 0.49 & 0.13 & 0.34 & 0.03 & 0.18 & 0.00 & 0.00 \\
\hline FT & 0.26 & 0.54 & 0.38 & 0.65 & 0.10 & 0.31 & 0.06 & 0.24 \\
\hline $\mathrm{TF}$ & 0.00 & 0.00 & 0.00 & 0.00 & 0.00 & 0.00 & 0.00 & 0.00 \\
\hline $\mathrm{T}$ & 0.00 & 0.00 & 0.00 & 0.00 & 0.00 & 0.00 & 0.00 & 0.00 \\
\hline FV & 0.00 & 0.00 & 0.13 & 0.34 & 0.03 & 0.18 & 0.06 & 0.24 \\
\hline VF & 0.00 & 0.00 & 0.00 & 0.00 & 0.00 & 0.00 & 0.00 & 0.00 \\
\hline $\mathrm{V}$ & 0.00 & 0.00 & 0.00 & 0.00 & 0.00 & 0.00 & 0.00 & 0.00 \\
\hline FY & 0.26 & 0.54 & 0.13 & 0.34 & 0.47 & 0.86 & 0.33 & 0.69 \\
\hline YF & 0.09 & 0.29 & 0.13 & 0.45 & 0.00 & 0.00 & 0.00 & 0.00 \\
\hline $\mathrm{Y}$ & 0.00 & 0.00 & 0.00 & 0.00 & 0.00 & 0.00 & 0.03 & 0.17 \\
\hline $\mathrm{Fr}$ & 0.00 & 0.00 & 0.08 & 0.41 & 0.00 & 0.00 & 0.06 & 0.24 \\
\hline $\mathrm{rF}$ & 0.00 & 0.00 & 0.00 & 0.00 & 0.00 & 0.00 & 0.00 & 0.00 \\
\hline Sum C' & 0.52 & 0.73 & 0.46 & 0.59 & 0.37 & 0.67 & 0.24 & 0.50 \\
\hline Sum T & 0.26 & 0.54 & 0.38 & 0.65 & 0.10 & 0.31 & 0.06 & 0.24 \\
\hline Sum V & 0.00 & 0.00 & 0.13 & 0.34 & 0.03 & 0.18 & 0.06 & 0.24 \\
\hline Sum Y & 0.35 & 0.57 & 0.25 & 0.61 & 0.47 & 0.86 & 0.36 & 0.70 \\
\hline Sum Shading & 1.13 & 1.14 & 1.21 & 1.02 & 0.97 & 1.16 & 0.73 & 1.04 \\
\hline
\end{tabular}


Ribeiro, R. K. S. M., Semer, N. L. \& Yazigi, L. (2011). Rorschach Comprehensive System Norms in Brazilian Children from Public and Private Schools.

(Continuation of the Table 10)

Statistical Distribution of the 113 Rorschach Variables of Children from Public Schools $(N=101)$

\begin{tabular}{|c|c|c|c|c|c|c|c|c|}
\hline \multirow[t]{2}{*}{ Variables } & \multicolumn{2}{|c|}{7 year olds $(N=23)$} & \multicolumn{2}{|c|}{8 year olds $(N=24)$} & \multicolumn{2}{|c|}{9 year olds $(N=30)$} & \multicolumn{2}{|c|}{10 year olds $(N=33)$} \\
\hline & $M$ & $S D$ & $M$ & $S D$ & $M$ & $S D$ & $M$ & $S D$ \\
\hline $\mathrm{Fr}+\mathrm{rF}$ & 0.00 & 0.00 & 0.08 & 0.41 & 0.00 & 0.00 & 0.06 & 0.24 \\
\hline FD & 0.43 & 0.73 & 0.21 & .059 & 0.33 & 0.71 & 0.21 & 0.78 \\
\hline $\mathrm{F}$ & 10.91 & 2.95 & 10.79 & 2.93 & 11.37 & 3.18 & 11.09 & 2.67 \\
\hline Pair & 2.43 & 2.27 & 3.17 & 2.68 & 3.83 & 3.28 & 4.27 & 2.99 \\
\hline $3 r+(2) / R$ & 0.16 & 0.15 & 0.21 & 0.18 & 0.24 & 0.20 & 0.29 & 0.19 \\
\hline Lambda & 5.27 & 5.03 & 4.30 & 4.55 & 4.60 & 4.51 & 4.46 & 4.50 \\
\hline PureF\% & 0.73 & 0.22 & 0.69 & 0.18 & 0.71 & 0.18 & 0.71 & 0.17 \\
\hline $\mathrm{FM}+\mathrm{m}$ & 1.52 & 1.41 & 2.33 & 2.28 & 2.20 & 2.23 & 2.42 & 2.06 \\
\hline EA & 2.28 & 2.90 & 2.19 & 2.12 & 2.07 & 1.79 & 2.03 & 1.87 \\
\hline es & 2.65 & 2.31 & 3.54 & 2.34 & 3.17 & 2.20 & 3.15 & 2.31 \\
\hline D Score & 0.00 & 0.85 & -0.17 & 0.56 & -0.17 & 0.38 & -0.18 & 0.68 \\
\hline Adj D & 0.00 & 0.85 & -0.04 & 0.46 & -0.07 & 0.37 & -0.03 & 0.47 \\
\hline a (active) & 1.00 & 1.24 & 1.83 & 2.18 & 2.13 & 2.46 & 2.33 & 2.57 \\
\hline $\mathrm{p}$ (passive) & 0.78 & 0.85 & 1.21 & 1.41 & 1.20 & 1.61 & 1.33 & 1.29 \\
\hline $\mathrm{Ma}$ & 0.13 & 0.34 & 0.25 & 0.53 & 0.83 & 1.26 & 0.82 & 1.21 \\
\hline $\mathrm{Mp}$ & 0.13 & 0.34 & 0.29 & 0.62 & 0.23 & 0.43 & 0.42 & 0.61 \\
\hline Intellect & 0.22 & 0.42 & 0.54 & 0.59 & 0.27 & 0.45 & 0.39 & 0.70 \\
\hline $\mathrm{Zf}$ & 6.48 & 3.26 & 7.42 & 3.15 & 5.50 & 3.43 & 6.82 & 3.23 \\
\hline $\mathrm{Zd}$ & -0.70 & 3.97 & 0.23 & 2.14 & 0.58 & 2.70 & -0.52 & 2.85 \\
\hline Blends & 0.83 & 1.03 & 1.00 & 1.29 & 0.60 & 0.81 & 0.76 & 1.09 \\
\hline Blends/R & 0.05 & 0.06 & 0.07 & 0.09 & 0.04 & 0.05 & 0.05 & 0.07 \\
\hline Col.Shd Blends & 0.09 & 0.29 & 0.13 & 0.45 & 0.10 & 0.31 & 0.00 & 0.00 \\
\hline Afr & 0.58 & 0.23 & 0.55 & 0.17 & 0.62 & 0.25 & 0.54 & 0.25 \\
\hline Popular & 2.57 & 1.27 & 2.75 & 1.29 & 2.77 & 1.38 & 3.24 & 1.30 \\
\hline XA\% & 0.59 & 0.16 & 0.61 & 0.13 & 0.66 & 0.12 & 0.66 & 0.15 \\
\hline WDA\% $\%$ & 0.69 & 0.18 & 0.67 & 0.15 & 0.73 & 0.13 & 0.73 & 0.11 \\
\hline$X+\%$ & 0.36 & 0.13 & 0.37 & 0.14 & 0.41 & 0.11 & 0.44 & 0.13 \\
\hline $\mathrm{X}-\%$ & 0.38 & 0.15 & 0.37 & 0.14 & 0.32 & 0.12 & 0.32 & 0.15 \\
\hline $\mathrm{Xu} \%$ & 0.23 & 0.09 & 0.24 & 0.15 & 0.26 & 0.12 & 0.23 & 0.12 \\
\hline Isolate/R & 0.12 & 0.16 & 0.13 & 0.15 & 0.12 & 0.13 & 0.13 & 0.14 \\
\hline $\mathrm{H}$ & 0.74 & 0.96 & 0.88 & 0.85 & 1.33 & 1.18 & 1.21 & 1.27 \\
\hline$(\mathrm{H})$ & 0.52 & 0.73 & 0.42 & 0.72 & 0.47 & 0.90 & 0.48 & 0.67 \\
\hline $\mathrm{Hd}$ & 1.30 & 1.18 & 0.75 & 1.26 & 1.50 & 1.78 & 0.85 & 1.06 \\
\hline$(\mathrm{Hd})$ & 0.22 & 0.52 & 0.08 & 0.28 & 0.40 & 0.62 & 0.27 & 0.57 \\
\hline $\mathrm{Hx}$ & 0.04 & 0.21 & 0.00 & 0.00 & 0.03 & 0.18 & 0.03 & 0.17 \\
\hline $\mathrm{H}+(\mathrm{H})+\mathrm{Hd}+(\mathrm{Hd})$ & 2.78 & 1.81 & 2.13 & 1.78 & 3.70 & 2.56 & 2.82 & 2.10 \\
\hline$(\mathrm{H})+\mathrm{Hd}+(\mathrm{Hd})$ & 2.04 & 1.40 & 1.25 & 1.33 & 2.37 & 1.94 & 1.61 & 1.43 \\
\hline A & 7.09 & 2.73 & 8.29 & 2.74 & 7.30 & 2.37 & 8.45 & 3.30 \\
\hline (A) & 0.26 & 0.62 & 0.29 & 0.55 & 0.17 & 0.46 & 0.21 & 0.42 \\
\hline Ad & 1.87 & 1.84 & 1.79 & 2.64 & 2.47 & 2.83 & 2.12 & 2.23 \\
\hline (Ad) & 0.09 & 0.29 & 0.00 & 0.00 & 0.13 & 0.43 & 0.24 & 0.50 \\
\hline An & 1.09 & 1.59 & 0.92 & 1.64 & 0.87 & 1.28 & 0.45 & 0.71 \\
\hline Art & 0.17 & 0.39 & 0.54 & 0.59 & 0.23 & 0.43 & 0.36 & 0.70 \\
\hline Ay & 0.04 & 0.21 & 0.00 & 0.00 & 0.03 & 0.18 & 0.03 & 0.17 \\
\hline $\mathrm{Bl}$ & 0.48 & 0.73 & 0.42 & 0.78 & 0.13 & 0.35 & 0.12 & 0.42 \\
\hline $\mathrm{Bt}$ & 0.61 & 1.20 & 0.29 & 0.55 & 0.53 & 0.73 & 0.55 & 0.62 \\
\hline $\mathrm{Cg}$ & 0.48 & 0.85 & 0.67 & 1.09 & 1.00 & 1.17 & 0.82 & 1.33 \\
\hline $\mathrm{Cl}$ & 0.00 & 0.00 & 0.04 & 0.20 & 0.03 & 0.18 & 0.03 & 0.17 \\
\hline
\end{tabular}


(Continuation of the Table 10)

Statistical Distribution of the 113 Rorschach Variables of Children from Public Schools $(N=101)$

\begin{tabular}{|c|c|c|c|c|c|c|c|c|}
\hline \multirow[t]{2}{*}{ Variables } & \multicolumn{2}{|c|}{7 year olds $(N=23)$} & \multicolumn{2}{|c|}{8 year olds $(N=24)$} & \multicolumn{2}{|c|}{9 year olds $(N=30)$} & \multicolumn{2}{|c|}{10 year olds $(N=33)$} \\
\hline & $M$ & $S D$ & $M$ & $S D$ & $M$ & $S D$ & $M$ & $S D$ \\
\hline Ex & 0.04 & 0.21 & 0.00 & 0.00 & 0.00 & 0.00 & 0.00 & 0.00 \\
\hline $\mathrm{Fi}$ & 0.39 & 0.78 & 0.38 & 0.77 & 0.27 & 0.52 & 0.30 & 0.64 \\
\hline $\mathrm{Fd}$ & 0.00 & 0.00 & 0.21 & 0.66 & 0.03 & 0.18 & 0.00 & 0.00 \\
\hline $\mathrm{Ge}$ & 0.00 & 0.00 & 0.00 & 0.00 & 0.07 & 0.25 & 0.00 & 0.00 \\
\hline $\mathrm{Hh}$ & 0.00 & 0.00 & 0.29 & 0.55 & 0.27 & 0.64 & 0.06 & 0.24 \\
\hline Ls & 0.09 & 0.29 & 0.13 & 0.45 & 0.20 & 0.61 & 0.12 & 0.33 \\
\hline $\mathrm{Na}$ & 0.57 & 1.04 & 0.75 & 1.03 & 0.50 & 0.78 & 0.67 & 0.92 \\
\hline $\mathrm{Sc}$ & 0.26 & 0.69 & 0.67 & 1.01 & 0.53 & 0.90 & 0.45 & 0.90 \\
\hline $\mathrm{Sx}$ & 0.00 & 0.00 & 0.00 & 0.00 & 0.00 & 0.00 & 0.00 & 0.00 \\
\hline Xy & 0.00 & 0.00 & 0.00 & 0.00 & 0.00 & 0.00 & 0.03 & 0.17 \\
\hline Id & 0.35 & 0.57 & 0.54 & 0.83 & 0.43 & 0.82 & 0.30 & 0.59 \\
\hline $\mathrm{An}+\mathrm{Xy}$ & 1.09 & 1.59 & 0.92 & 1.64 & 0.87 & 1.28 & 0.48 & 0.71 \\
\hline DV & 0.39 & 0.58 & 0.33 & 0.56 & 0.23 & 0.50 & 0.33 & 0.60 \\
\hline INCOM & 0.39 & 0.72 & 0.17 & 0.38 & 0.30 & 0.47 & 0.30 & 0.68 \\
\hline DR & 0.30 & 0.63 & 0.33 & 0.64 & 0.17 & 0.46 & 0.18 & 0.53 \\
\hline FABCOM & 0.13 & 0.34 & 0.33 & 0.64 & 0.17 & 0.53 & 0.21 & 0.48 \\
\hline DV2 & 0.00 & 0.00 & 0.00 & 0.00 & 0.00 & 0.00 & 0.00 & 0.00 \\
\hline INCOM2 & 0.00 & 0.00 & 0.00 & 0.00 & 0.00 & 0.00 & 0.00 & 0.00 \\
\hline DR2 & 0.00 & 0.00 & 0.00 & 0.00 & 0.00 & 0.00 & 0.00 & 0.00 \\
\hline FABCOM2 & 0.13 & 0.46 & 0.08 & 0.28 & 0.10 & 0.40 & 0.12 & 0.33 \\
\hline ALOG & 0.04 & 0.21 & 0.04 & 0.20 & 0.00 & 0.00 & 0.00 & 0.00 \\
\hline CONTAM & 0.00 & 0.00 & 0.00 & 0.00 & 0.03 & 0.18 & 0.00 & 0.00 \\
\hline Sum6 Sp Sc & 1.39 & 1.31 & 1.29 & 1.33 & 1.00 & 1.49 & 1.15 & 1.48 \\
\hline Lvl $2 \mathrm{Sp} \mathrm{Sc}$ & 0.13 & 0.46 & 0.08 & 0.28 & 0.10 & 0.40 & 0.12 & 0.33 \\
\hline WSum6 & 3.74 & 4.45 & 3.79 & 4.82 & 2.93 & 5.34 & 3.18 & 4.71 \\
\hline $\mathrm{AB}$ & 0.00 & 0.00 & 0.00 & 0.00 & 0.00 & 0.00 & 0.00 & 0.00 \\
\hline $\mathrm{AG}$ & 0.04 & 0.21 & 0.21 & 0.41 & 0.17 & 0.38 & 0.39 & 1.00 \\
\hline $\mathrm{COP}$ & 0.00 & 0.00 & 0.13 & 0.34 & 0.17 & 0.46 & 0.21 & 0.48 \\
\hline $\mathrm{CP}$ & 0.00 & 0.00 & 0.00 & 0.00 & 0.00 & 0.00 & 0.00 & 0.00 \\
\hline Good HR & 1.22 & 1.28 & 1.04 & 1.27 & 1.67 & 1.49 & 1.48 & 1.37 \\
\hline Poor HR & 1.57 & 1.24 & 1.46 & 1.61 & 2.07 & 1.93 & 1.55 & 1.64 \\
\hline MOR & 0.22 & 0.67 & 0.63 & 1.28 & 0.07 & 0.25 & 0.30 & 0.59 \\
\hline PER & 0.26 & 0.54 & 0.33 & 0.70 & 0.40 & 1.00 & 0.36 & 0.82 \\
\hline PSV & 0.22 & 0.42 & 0.13 & 0.34 & 0.13 & 0.35 & 0.30 & 0.59 \\
\hline PTI Total & 1.78 & 1.28 & 1.83 & 1.34 & 1.17 & 1.23 & 1.27 & 1.28 \\
\hline DEPI Total & 3.22 & 0.80 & 3.58 & 0.88 & 3.53 & 0.82 & 3.12 & 0.78 \\
\hline CDI Total & 3.74 & 0.62 & 3.92 & 0.50 & 3.70 & 0.75 & 3.64 & 0.86 \\
\hline SCON Total & 5.30 & 1.36 & 5.38 & 1.50 & 5.00 & 1.02 & 4.88 & 1.47 \\
\hline HVI Total & 1.61 & 0.72 & 1.29 & 0.91 & 1.93 & 1.01 & 1.76 & 0.79 \\
\hline OBS Total (1-5) & 0.72 & 0.62 & 0.42 & 0.58 & 0.67 & 0.71 & 0.58 & 0.56 \\
\hline WD+ & 0.00 & 0.00 & 0.00 & 0.00 & 0.03 & 0.18 & 0.03 & 0.17 \\
\hline WDo & 5.22 & 1.95 & 5.58 & 2.19 & 6.00 & 1.66 & 6.55 & 2.03 \\
\hline WDu & 2.83 & 1.61 & 2.96 & 2.35 & 2.70 & 1.88 & 2.45 & 1.73 \\
\hline WD- & 3.43 & 2.23 & 3.88 & 2.05 & 3.20 & 1.79 & 3.12 & 1.54 \\
\hline WDNone & 0.35 & 0.57 & 0.25 & 0.53 & 0.23 & 0.43 & 0.12 & 0.42 \\
\hline EII_2 & 0.21 & 0.63 & 0.20 & 0.64 & 0.02 & 0.63 & 0.00 & 0.67 \\
\hline HRV & -0.35 & 1.75 & -0.42 & 2.02 & -0.40 & 2.34 & -0.06 & 2.01 \\
\hline
\end{tabular}




\section{Discussion}

The comparative analyses of the children from public and private schools revealed statistically significant differences in some variables that, according to Exner and Weiner (1995a) and Weiner (2000), mean that the children from private schools showed a greater freedom to associate and produce responses, a greater presence of situational stress, a better ability to cope with complex affective situations and a more intellectual handling of affect. These characteristics reveal that children from the more privileged social classes handle complex situations more easily, since they are perhaps more stimulated by their families and their school environment. They were also more anxious perhaps because they felt under more pressure and because they have to spend time on various extracurricular activities, according to the information provided by their parents in the CBCL.

The children from public schools, meanwhile, presented a more formal attitude and less variability of reactions, less involvement and a more simplified perception. These characteristics reveal that the children from the less privileged social classes possibly perceive the world in a more impersonal way, with less engagement of personal resources, a characteristic that seems to be related to a lower exposure to environmental stimulation. Exner and Weiner (1995a) pointed out that children from lower classes presented a higher Lambda than children from higher social classes, which can be confirmed in this study.

Comparative statistical analyses were conducted between the variables in the four age groups and the two school origins to verify differences in terms of gender. The results according to the " $t$-test", with a level of significance $(p<.05)$ and the Bonferroni correction, revealed that boys and girls obtain similar results in the Rorschach Comprehensive System variables. Exner and Weiner (1995a) had already encountered similar results between boys and girls in terms of location and determinants, which was confirmed in this study.

\section{Final Considerations}

Normative tables were created for the 113 Rorschach Comprehensive System variables, compiled by age group (7, 8, 9 and 10 years old) and school origin (private and public) that will provide support for professionals, both for research of clinical and non-clinical cases, and also input for psychological studies with Brazilian children in this age group. And it may also provide input for research considering children from different social, cultural and economic extractions.

It is important to continue making normative studies with children from different regions of Brazil to observe the distinctions and similarities in the way children respond to the Rorschach in virtue of social, cultural and economic context.
As can be observed, it is imperative for the studies in this field to consider the use of adequate instruments in the pre-selection of the sample, to consider the size of the sample and to consider the school origin (public and private) that addresses the different social classes.

\section{References}

Achenbach, T. M. (1991). Manual for the Child Behavior Checklist/4-18. Burlington, VT: University of Vermont, Department of Psychiatry.

Adrados, I. (1985). A técnica de Rorschach em crianças: Perfil psicológico da criança dos sete aos quatorze anos. Petrópolis, RJ: Vozes.

Angelini, A. L., Alves, I. C. B., Custódio, E. M., Duarte, W. F., \& Duarte, J. L. M. (1999). Manual das matrizes progressivas coloridas de Raven: Escala especial. São Paulo, SP: Centro Editor de Testes e Pesquisas em Psicologia.

Barreto, A. P. (1955). Psicodiagnóstico de Rorschach aplicado para crianças. Neurobiologia, 111(28), 169-182. (Original work published 1950)

Beck, S. J., Beck, A. G., Levitt, E. E., \& Molish, H. B. (1961). Rorschach's test: Basic processes ( $3^{\text {rd }}$ ed.). New York: Grune $\&$ Stratton.

Bordin, I. A. S., Duarte, C. S., Peres, C. A., Nascimento, R., Curto, B. M., \& Paula, C. S. (2009). Severe physical punishment: Risk of mental health problems for poor urban children in Brazil. Bulletin of the World Health Organization, 87(5), 336-344.

Bordin, I. A. S., Mari, J. J., \& Caeiro, M. F. (1995). Validação da versão brasileira do "Child Behavior Checklist" (CBCL) - inventário de comportamentos da infância e adolescência: Dados preliminares. Revista ABP-APAL, 17(2), 55-66.

Brasil, H. H. A. (2003). Desenvolvimento da versão brasileira da K-SADS-PL (Schedule for Affective Disorders and Schizophrenia for School Aged Children Present and Lifetime Version) e estudo de suas propriedades psicométricas. Tese de Doutorado não-publicada, Escola Paulista de Medicina, Universidade Federal de São Paulo, SP.

Brazilian Association of Market Research Institutes. (2008). Critério de classificação econômica Brasil. São Paulo, SP: Autor. Retrieved February 7, 2010, from http://www.abep.org

Exner, J. E., Jr. (1974). The Rorschach: A comprehensive system: Vol. 1. Basic foundations. New York: Wiley.

Exner, J. E., Jr. (1993). The Rorschach: A comprehensive system: Vol. 1. Basic foundations ( $3^{\text {rd }}$ ed.). New York: John Wiley \& Sons.

Exner, J. E., Jr., \& Weiner, I. B. (1995a). The Rorschach: A comprehensive system: Vol. 1. Basic foundations ( $3^{\text {rd }} \mathrm{ed}$.). New York: John Wiley \& Sons.

Exner, J. E., Jr., \& Weiner, I. B. (1995b). The Rorschach: A comprehensive system: Vol. 3. Assessment of children and adolescents ( $2^{\text {nd }}$ ed.). New York: John Wiley \& Sons.

Jacquemin, A. A. (1975). O teste de Rorschach em crianças brasileiras: Pesquisa e Atlas. São Paulo, SP: Vetor.

Klopfer, B., \& Boyer, L. B. (1961). Notes on the personality structure of a North American Indian shaman: Rorschach interpretation. Journal of Projective Techniques, 25, 170-178.

Meyer, G. J., Erdberg, P., \& Shaffer, T. W. (2007). Toward International Normative Reference Data for the Comprehensive System. Journal of Personality Assessment, 89(Suppl. 1), S201-S216. 
Pasquali, L. (2003). Psicometria: Teoria dos testes na psicologia e na educação. Petrópolis, RJ: Vozes.

Raspantini, R. L., \& Pasian, S. R. (2008). Psicodiagnóstico de Rorschach em crianças de nove a 11 anos: Dados preliminares. In S. R. Pasian, E. T. K. Okino, S. R. Loureiro, \& F. L. Osório (Eds.), Avaliação da personalidade: Técnicas e contextos atuais (pp. 221-237). Ribeirão Preto, SP: Associação Brasileira de Rorschach e Métodos Projetivos.

Raven, J., Raven, J. C., \& Court, J. H. (1993). Manual for Raven's Progressive Matrices and Vocabulary Scales. Section 1: General Overview. Oxford, UK: Oxford Psychologists Press.

Resende, A. C., Rezende, T. C., \& Martins, L. D. (2006). Estudo normativo do Rorschach para goianenses: Dados preliminares. In Associação Brasileira de Rorschach e Métodos Projetivos (Ed.), Anais IV Congresso Nacional da Associação Brasileira de Rorschach e Métodos Projetivos (pp. 124135). São Paulo, SP: Vetor.

Ribeiro, R. K. S. M., Semer, N. L., \& Yazigi, L. (in press). Rorschach Comprehensive System Data from a Sample of 211 Nonpatient Children in Brazil. Journal of Personality Assessment.

Shaffer, T. W., Erdberg, P., \& Meyer, G. J. (2007). Introduction to the JPA Special Supplement on International Reference Samples for the Rorschach Comprehensive System. Journal of Personality Assessment, 89(Suppl. 1), S2-S6.

Viana, G. C. (1958). As respostas de crianças de 03 a 08 anos ao Psicodiagnóstico de Rorschach. Boletim do Instituto de Psicologia, 8(3-4), 20-31.

Weiner, I. B. (2000). Princípios da interpretação do Rorschach. São Paulo, SP: Casa do Psicólogo.

Windholz, M. H. (1969). Rorschach em crianças. São Paulo, SP: Vetor. 